\title{
Evaluation of Seismic Behavior in Building Tube Structures System with Respect to Dense Soil-Structure Interaction Effect
}

\author{
Moreteza Deiranlou \\ Instructor of Faculty, Esfarayen University of Technology, Esfarayen, Iran \\ Email:m.deiranlou@yahoo.com
}

Received 7 November 2015; accepted 14 December 2015; published 17 December 2015

Copyright @ 2015 by author and Scientific Research Publishing Inc.

This work is licensed under the Creative Commons Attribution International License (CC BY). http://creativecommons.org/licenses/by/4.0/

(c) (i) Open Access

\begin{abstract}
The perceiving local site effects on strong ground motion are particularly important for the mitigation of earthquake disasters as well as future earthquake resistant design. The primary objective of this study is to investigate seismic behavior of building tube structure system with respect to dense soil-structure interaction (sand dense and very hard clay soil with a thickness greater than $30 \mathrm{~m}$ ). For this purpose, the studied building in this paper is placed over two other different modeled soil types and results of seismic behavior of building for three soil types are compared with each other. Through response spectrum analyses, influence of different sub-soils (dense and loose soil) was determined on seismic behavior of 40-storey building reinforced concrete (RC) with tube in tube structure system and performance of each model was assessed in terms of shear lag behavior, overall and critical (maximum) story drifts. Results illustrate that loose soils amplify seismic waves and increase building drifts and shear lag behavior.
\end{abstract}

\section{Keywords}

Response Spectrum Analysis, Earthquake, Compacted Soil, Soil-Structure Interaction

\section{Introduction}

Recent improvements in seismological source modeling, analysis of travel path effects, and characterization of local site effects on strong vibration have led to significant advances in both code-based and more advanced procedures for evaluating seismic demand for structural design. Seismic wave's propagation through near-surface soil layers can produce ground motions much larger on the soil surface with different characteristics than those recorded at the rock base. 
The combined effect of earthquakes and local site conditions are commonly referred as site effects.

Numerous examples of earthquakes are available where site effects were observed. As an example during Mexico City earthquake [1], site amplification caused substantial damage and collapse of many buildings [1]. Detailed studies on the relationship between building damage and soil conditions were provided by Seed [2]. In addition, there are numerous studies which have shown correlation between damage and local geology and site condition [3]-[5]. Many researchers studied seismic analysis on soil-structure interaction for different types of structures including bridges, minarets, etc. [6]-[9]. Analysis of soil-structure interaction effects during earthquakes is usually made by one of two methods [10]: 1) a complete interaction analysis involving consideration of the variation of motions in the structure and in the adjacent soil, or 2) an internal analysis in which the motions in the adjacent soil are assumed to be the same at all points above foundation depth. Different aspects of seismic soil-structure interaction analysis are investigated by different researchers which are also available in the literature including studies of [11] and [12]. A building framed-tube system is considered one of the most efficient lateral force-resisting systems. This system utilizes closely spaced perimeter columns tied to each other with spandrel beams, often in combination with additional bracing components (e.g., outriggers or belt walls). In general, the lateral force resistance of the framed-tube system is highly promoted by the aid of tube action. The tube action is perceived as the behavior of a system that acts like a cantilever box beam when subjected to overturning moment induced by lateral loading, with a significant contribution by the flange elements (Figure 1) [13] [14]. During the tube action, unfavorable shear lag inevitably occurs. The shear lag phenomenon is characterized by non-uniform axial forces or stresses applied in the columns or walls of the peripheral flanges and/or by nonlinear stress distributions in the peripheral webs (Figure 1). ETABS (v9.2.0; [15]) program has been used for simulation of the whole project including the local soil and the building structure.

\section{Properties of the Simulated Soil}

Table 1 describes three soil types that simulated in this paper, type a soil defined as sand dense and very hard clay with a thickness greater than $30 \mathrm{~m}$, type b soil description as soil with average density, clay with average hardness and shattered stone by weathering and soil type c with assumed soft soil with high humidity due to high surface ground water defined specifications. $V_{s}$ parameter illustrates shear wave velocity in soil layers, in case of lack of $V_{s}$ parameter could use N1 (60) parameter for aggregate soil and Cu parameter for adhesive soil. $\mathrm{N} 1$ (60) parameter marker number of blows modified penetration standard and $\mathrm{Cu}$ parameter shows average undrained shear resistance. $V_{s}$ parameter is shear wave velocity in soil layers that can be used up to $30 \mathrm{~m}$ depth, it can be derived from Formula (1), in Formula (1) $D_{i}$ and $V_{s i}$ parameters marker thickness of soil and shear wave velocity in the soil layer, $\mathrm{Cu}$ and $\mathrm{N} 1$ (60) are calculated similar to $V_{s}$ parameter.

$$
V_{s}=\frac{\sum D_{i}}{\sum\left(D_{i} / V_{s i}\right)}
$$
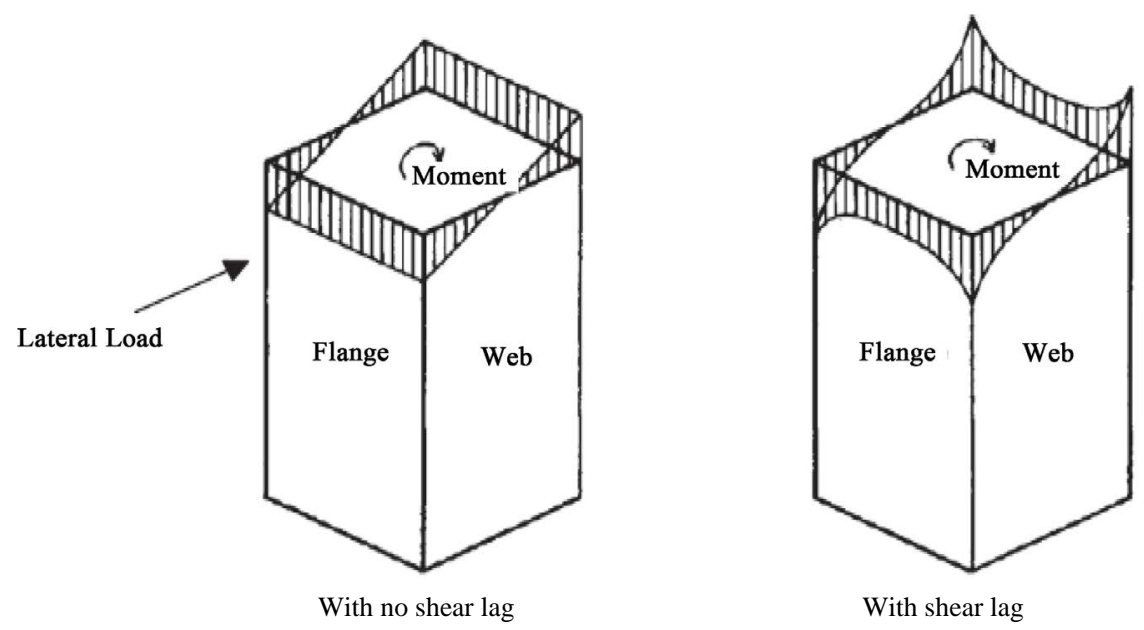

Figure 1. Shear lag occurring during tube action [14]. 
Table 1. Properties simulated soils.

\begin{tabular}{clccc}
\hline \multirow{2}{*}{ Type of soil } & Description properties soil & \multicolumn{3}{c}{ Parameters } \\
\cline { 3 - 4 } & & $V_{s}(\mathrm{~m} / \mathrm{s})$ & $\mathrm{N} 1(60)$ & $\mathrm{Cu}(\mathrm{kpa})$ \\
\hline a & $\begin{array}{c}\text { Sand dense and very hard clay } \\
\text { with a thickness of more than } 30 \mathrm{~m} \\
\text { - Soil with average density }\end{array}$ & $375-750$ & More than 50 & More than 250 \\
b & $\begin{array}{l}\text { - Clay with average hardness } \\
\text { - Shattered stone by weathering } \\
\text { Soft hypothesis with high humidity } \\
\text { due to high surface groundwater }\end{array}$ & Less than 175 & Less than 15 & Less than 70 \\
\hline
\end{tabular}

\section{Structural and Modeling System of the Case Study Building}

Figure 2 illustrates 40-storey concrete building plan and ETABS model, the structure is with $148 \mathrm{~m}$ height, 21.6 $\times 21.6 \mathrm{~m}$ width and length at the lower, the structural system made entirely of RC, consists of closely columns with $100 \times 100 \mathrm{~cm}$ dimension, $100 \times 80 \mathrm{~cm}$ spandrel beam and interior (core) walls with $70 \mathrm{~cm}$ thickness surrounding elevator shafts and stair openings. First story height is $4 \mathrm{~m}$ and upper floors height is $3.6 \mathrm{~m}$, concrete compressive strengths are considered for all members $350\left(\mathrm{~kg} / \mathrm{cm}^{\wedge} 2\right)$ and the proposed slab thickness is $300 \mathrm{~mm}$ for all floors. ETABS building analysis and design software (v9.7.0; Computers and Structures Inc. [15]-[17]) has been used for the modeling and analysis of this study. Several important modeling and analysis approaches used for this study are summarized in the following:

1) Joints between the beams and columns (parts of both the beams and columns belonging to their common regions) are assumed rigid.

2) The contribution of the slab to the beam stiffness (i.e., T-beam action) is ignored.

3) The concrete floors are modeled with rigid diaphragm constraints for lateral force analysis.

4) P-delta effects are taken into account by an approximation method imbedded in ETABS (CSI, 2011).

5) The flexural stiffness of uncracked shear walls is assumed to correspond to $100 \%$ of the cross-section properties, while the flexural stiffness of all spandrel beams and coupling beams is taken as $50 \%$ based on ACI 318-08, Section 8.8 [18]. It has been verified from the models that the shear walls are expected not to be undergone by cracking at all stories under the lateral forces used for this study. Detailed discussions for the finite element modeling of cracked shear walls can be found elsewhere (Shin et al., 2010).

\section{Response Spectrum Analysis}

Seismic response of a soil-structure interaction system is affected by many factors during the earthquake including the soil type and parameters (shear modulus, mass density and material damping), structure's height and its materials' properties. Analyses are performed for 40-storey building so as to investigate the effect of building's height and the soil type on acceleration response of the whole system. Figure 3 shows acceleration for different structure's periods that produced by each simulated soil type, the studied building's period was calculated about 2.12 second. As you can see in Figure 3, soil type c gives the most acceleration for a period near to studied building's period and soil type a (sand dense and very hard clay with a thickness greater than $30 \mathrm{~m}$ ) gives less acceleration for a period near to studied building's period.

\section{Storey Drifts}

Figure 4 shows story drifts along the building height for three soil types modeled with different properties under the service-level earthquake forces, as you can see building that located over soft hypothesis soil with high humidity due to high surface groundwater shows the most overall story drift and story drift, and building that located over soil type a and b shows significant decrease in overall building drift, overall building drift for building that located over sand dense and very hard clay with a thickness of more than 30 m reduction over 50\% proportional to building that is located over the assumed soil with high humidity due to high surface groundwater and building story drift that is located over soil type a reduction as well as over 50\% proportional to building that is located over soil type c. 


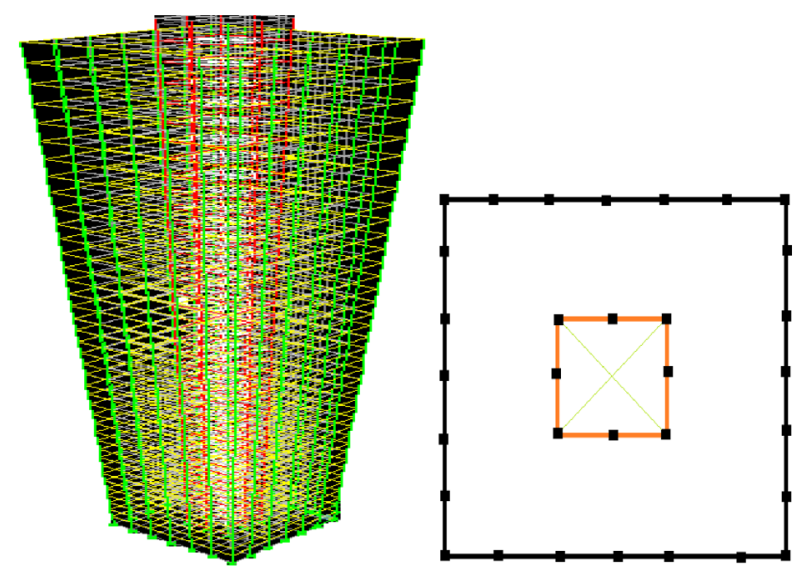

Figure 2. Building plan and Etabs model of the case study building.

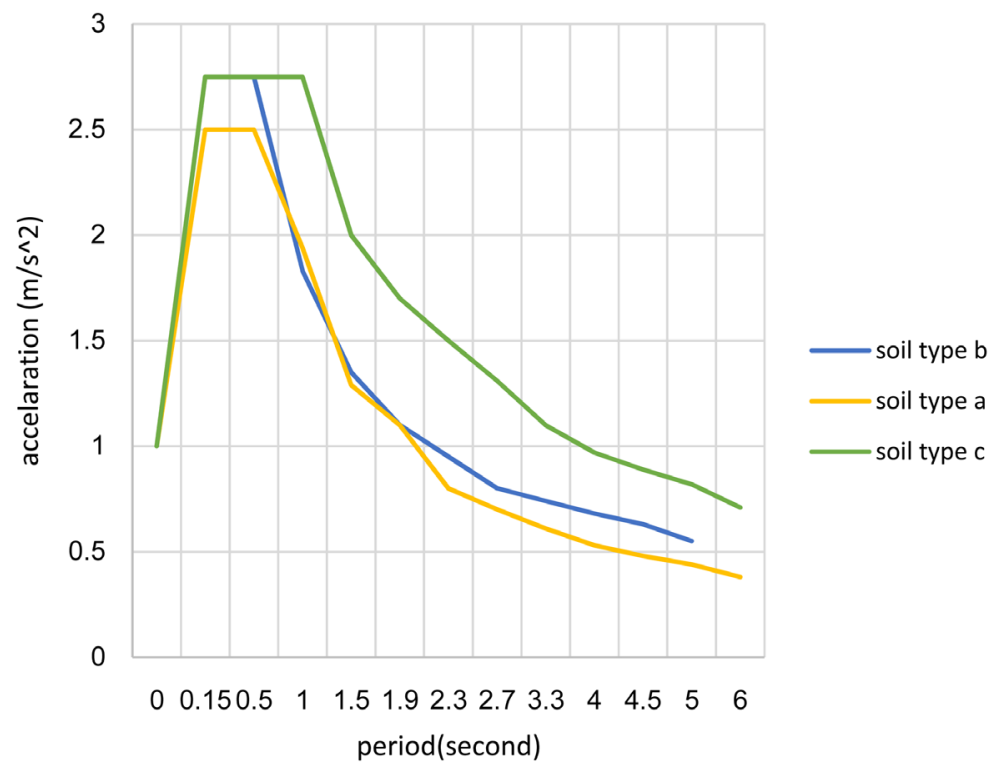

Figure 3. Shows acceleration for different periods.
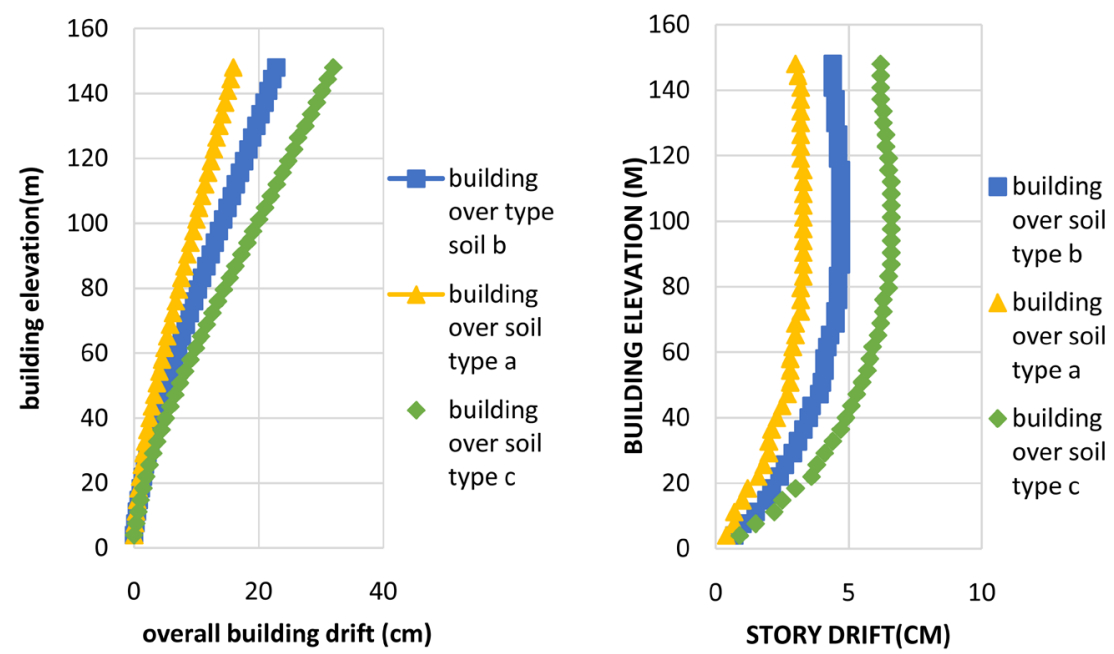

Figure 4. Overall building drift and story drift for building that is located over soil type a, b and c. 


\section{Distribution of Column Axial Force}

During the tube action, unfavorable shear lag occurs inevitably. The shear lag phenomenon is characterized by non-uniform axial forces or stresses applied in the columns or walls of the peripheral flanges and/or by nonlinear stress distributions in the peripheral webs. Two different shear lag modes may exist in building tube systems: 1) positive shear lag and 2) negative shear lag. Positive shear lag is characterized in such a way that corner columns take larger axial forces than middle columns under bending of the building, and vice versa for negative shear lag. Figure 5 shows columns axial force for first, tenth and twentieth floors for building that is located over soil type a, b and c. As you can see in figure, building that is located over sand dense and very hard clay with a thickness greater than $30 \mathrm{~m}$ shows least columns axial force and have situated nearest to the ideal state (linear distribution axial force) as well as building over sand dense and very hard clay with a thickness greater than 30m shows approximately 50\% reduction corner column axial force proportional to building over the assumed soft soil with high humidity due to high surface groundwater and 30\% reduction corner column axial force proportional to building over soil with average density, clay with average hardness and shattered stone by weathering at the first, tenth and twentieth floors.

\section{Conclusions}

From Figures 5-7, we conclude the following results:

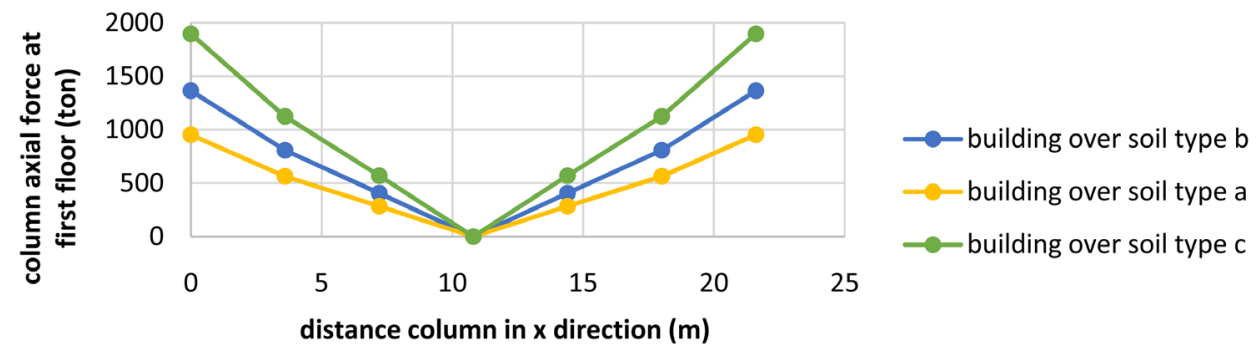

Figure 5. Distribution of column axial force at first floor.

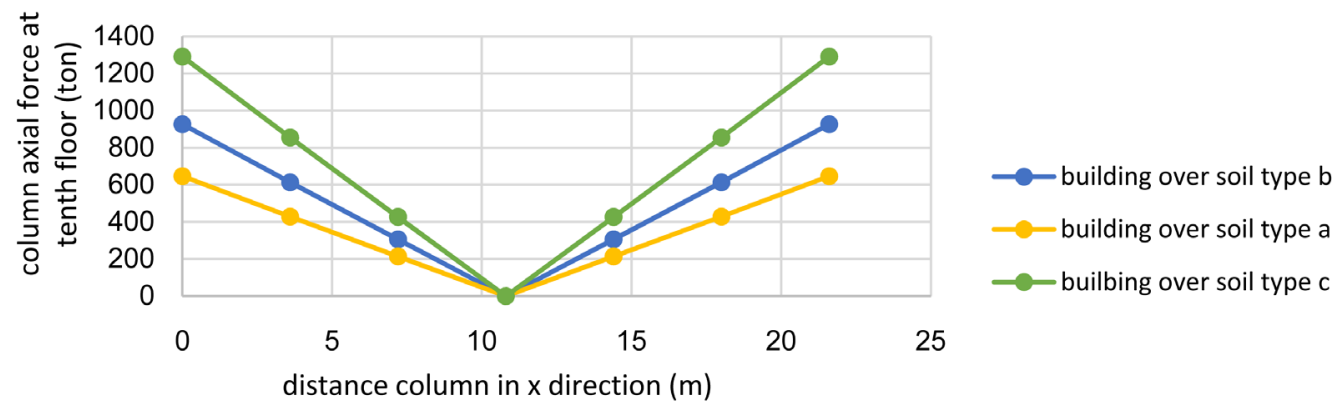

Figure 6. Distribution of column axial force at tenth floor.

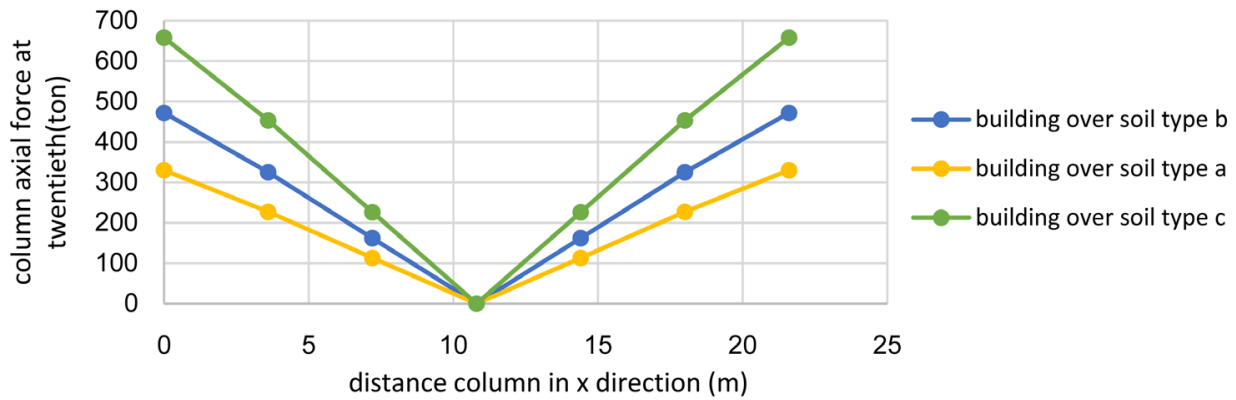

Figure 7. Distribution of column axial force at twentieth floor. 
1) Between three soil types, sand dense and very hard clay with a thickness greater than $30 \mathrm{~m}$, soil type a produces least acceleration for case study building, soil with average density, clay with average hardness and shattered stone by weathering (soil type b) and soft hypothesis soil with high humidity due to high surface groundwater (soil type c) in order to produce the maximum acceleration for case study building.

2) For short-period systems, the assumed soft soil is demonstrated with high humidity due to high surface groundwater that shows highest amplification for earthquake waves.

3) In case study building over sand dense and very hard clay with a thickness greater than $30 \mathrm{~m}$, soil type a shows 50 percent decrease less than overall building drift and story drift proportional to case study building over the assumed soft soil with high humidity due to high surface groundwater (soil type c) and 30 percent decrease less than overall building drift and story drift proportional to case study building over soil with average density, clay with average hardness and shattered stone by weathering (soil type b).

4) Distribution of axial column force for case study building that is located over soil type a is situated in nearest position to ideal state; in ideal state distribution of axial column force is similar to linear mode. For case study building over sand dense and very hard clay with a thickness of greater than $30 \mathrm{~m}$, soil type a shows 50 percent decrease less than corner and middle column axial force proportional to case study building over the assumed soft soil with high humidity due to high surface groundwater (soil type c) and 30 percent decrease less than corner and middle column axial force proportional to case study building over soil with average density, clay with average hardness and shattered stone by weathering (soil type b).

\section{References}

[1] Romo, M.P. and Seed, H.B. (1986) Analytical Modeling of Dynamic Soil Response in Mexico Earthquake of September 19th 1985. Proceedings of International Conference on the 1985 Mexico Earthquake, Mexico City, 19-21 September 1986, 148-162.

[2] Seed, H.B. (1986) Influence of Local Soil Conditions on Ground Motions and Building Damage during Earthquakes. The 8th Nabor Carillo Lecture, Presented at the Mexican Society for Soil Mechanics 13th National Meeting, Mazatlan, 8-10 September 1986.

[3] Ghosh, B. and Madabhushis, P.G. (2003) Effects of Localised Soil Inhomogeneity in Modifying Seismic Soil Structure Interaction. Proceedings of the 16th ASCE Engineering Mechanics Conference, Seattle, 16-18 July 2003.

[4] Heidebrecht, A.C., Henderson, P., Naumoski, N. and Pappin, J.W. (1990) Seismic Response and Design for Structures Located on Soft Clay Sites. Canadian Geotechnical Engineering Journal, 27, 330-341.

http://dx.doi.org/10.1139/t90-044

[5] Ohsaki, Y. (1969) Effects of Local Soil Conditions upon Earthquake Damage. Seventh International Conference on Soil Mechanics and Foundation Engineering, México City, 1969, 3-32.

[6] Council of Tall Buildings and Urban Habitant (1979) Structural Design of Tall Steel Buildings. Monograph of Planning and Design of Tall Buildings, American Society of Civil Engineers, Vol. SB, New York, 1077 p.

[7] Doganguan, A., Livaoglue, R. and Acar, R. (2007) A Study on Seismic Behavior of Minarets Considering Soil-Structure Interaction. International Earthquake Symposium, Kocaeli, 393-404.

[8] Howe, M. (2005) Uncertainty and Soil-Structure Interaction Effects on the Seismic Response Evaluations of Base Isolated Bridge Structures. PhD Thesis, Graduate School of Science and Engineering, Kagoshima University, Kagoshima.

[9] Mwafy, A.M., Kwon, O.S. and Elnashai, A.S. (2008) Inelastic Seismic Response of a 59-Span Bridge with SoilStructure Interaction. The 14th World Conference on Earthquake Engineering, Beijing, 12-17 October 2008.

[10] Rahgozar, M.A. (1993) Seismic Soil-Structure Interaction Analysis of Structural Base Shear Amplification. Thesis, Carleton University, Ottawa.

[11] Gazetas, G. (2006) Seismic Design of Foundation and Soil-Structure Interaction. First European Conference on Earthquake Engineering and Seismology, Geneva, Paper Number: Keynote Address K7.

[12] Kolekova, Y., Schmid, G. and Stojanovski, K. (2007) Soil-Structure Interaction under Seismic Excitation. Slovak Journal of Civil Engineering, 15, 18-21.

[13] Haji-Kazemi, H. and Company, M. (2002) Exact Method of Analysis of Shear Lag in Framed Tube Structures. The Structural Design of Tall Buildings, 11, 375-388. http://dx.doi.org/10.1002/tal.208

[14] Kwan, M. (1996) Shear Lag in Shear/Core Walls. ASCE Journal of Structural Engineering, 122, 1097-1104. http://dx.doi.org/10.1061/(ASCE)0733-9445(1996)122:9(1097)

[15] Computers and Structures Inc. (2005) CSI Analysis Reference Manual. Computers and Structures Inc., Berkeley. 
[16] Chang, P.C. and Foutch, D.A. (1984) Static and Dynamic Modeling and Analysis of Tube Frames. ASCE Journal of Structural Engineering, 110, 2955-2975. http://dx.doi.org/10.1061/(ASCE)0733-9445(1984)110:12(2955)

[17] Kristek, V. and Bauer, K. (1993) Stress Distribution in Front Columns of High Rise Buildings. ASCE Journal of Structural Engineering, 115, 1326-1337.

[18] ACI 318 (2008) Building Code Requirements for Structural Concrete (ACI 318-08) and Commentary (318R-08). American Concrete Institute, Farmington Hills. 